\section{ADMIRAL SIR ERASMUS OMMANNEY, K.C.B., F.R.S.}

A WELL-KNOWN figure has been lost to scientific A circles by the death of Admiral Sir Erasmus Ommanney, K.C.B., F.R.S., which occurred on December $2 \mathrm{I}$, at ninety years of age.

Erasmus Ommanney was born in London so long ago as the year 1814, and entered the Navy in 1826 . $\mathrm{He}$ became Lieutenant Ommanney in 1835 , and at once volunteered to serve under Sir James Ross in the voyage for the relief of a number of missing whalers reported to be caught by the ice of Baffin's Bay, and on the coasts of Greenland and Labrador. The objects of the expedition were successfully carried out, notwithstanding the extreme danger of the navigation during the winter months.

In $185^{\circ}$ he was appointed second in command under Captain Horatio Austin on the Arctic expedition in search of Sir John Franklin; and in August of that year was the actual discoverer of the first winter quarters of Franklin's ships. $\mathrm{He}$ also directed an extensive system of sledge journeys, by which the coast of Prince of Wales Land was laid down. After his return from the Arctic he was elected a Fellow of the Royal Society for his services to science.

After his retirement in 1877 , he threw himself with zeal into the work of numerous learned societies, of which he was an energetic member. $\mathrm{He}$ was a Fellow of the Royal Geographical Society, and had been a member of the council. He was also a Fellow of the Royal Astronomical Society. An active member of the British Association, he had served upon its council, and went with it to Canada in $\mathrm{I}_{884}$ as treasurer, receiving on that occasion the honorary degree of LL.D. from the McGill University, Montreal.

The funeral took place at Mortlake Cemetery on Tuesday afternoon. Among the wreaths placed upon the coffin was one from the president and members of the Royal Geographical Society.

\section{NOTES}

IT is proposed to establish in the University of Liverpool a memorial to Mr. R. W. H. T. Hudson, late lecturer in mathematics, whose brilliant career was so tragically cut short at the end of last September. The memorial will probably take the form of an annual prize in mathematics, to be awarded for distinction in geometry, the subject in which Mr. Hudson's work chiefly lay. For this purpose a sum of $\mathrm{rool}$. would be required. Contributions to the fund should be sent to Mr. Alexander Mair, the University, Liverpool.

Dr. J. Macintosh Bell, a nephew of Dr. Robert Bell, F.R.S., has just been appointed Government geologist of New Zealand. Dr. MacIntosh Bell has seen much active service on the Canadian Geological Survey, having worked during four seasons under his uncle, the director. In the spring of 1899 he went with Dr. Robert Bell to Great Slave Lake, where he spent the following winter, and in 1900 he was sent to Great Bear Lake, several hundred miles further north. On his return he was employed in Igor and 1902 as geologist by the Lake Superior Commercial Co., and in 1903 by the Ontario Bureau of Mines.

REPLirivg to a vote of thanks, after laying the foundationstone of the Chelmsford Free Library, School of Art, and Museum on December 2r, Lord Rayleigh said that the visit to Stockholm from which he had just returned was of great interest. His colleagues and he received almost a royal NO. I 835 , VOL. $7 \mathrm{I}]$ welcome, and at the banquet which formed part of the proceedings it was very much impressed upon them that what Nobel had in view in providing his prizes was to bring scientific men of the various countries together not merely for the advancement of science, but to promote good feeling and the cause of peace between the nations of the world. Lady Rayleigh afterwards distributed the prizes to the students of the local science and art classes.

LORD KELVIN has accepted the nomination of the council for the presidency of the Faraday Society, in succession to Sir Joseph Swan, F.R.S.

The death is announced of the Rev. J. M. Bacon at the age of fifty-eight. $\mathrm{Mr}$. Bacon had made a number of balloon ascents for scientific purposes, and some of the results of his studies are described in his works "The Dominion of the Air" and "By Land and Sky."

According to the Patria, negotiations have been entered upon by the Italian Minister of Posts and Telegraphs and the British Postmaster-General with a view to establish wireless telegraphic communication between the stations of Poldhu and Bari.

We are informed that the constitutional amendment exempting the California Academy of Sciences from further taxation was carried at the election, November 8 , by a majority of nearly $1 \mathrm{I}, 000$.

ThE bog-slide reported in several newspapers as having occurred on December 7 between Frenchpark and Castlerea in the north part of the county of Roscommon, appears now to have come to rest, after invading a village and covering a large area of agricultural land. Local information reaches us to the effect that clefts still remain visible in the bog, but that the hollow formed at the origin of the slide is gradually closing in. The flow is attributed to heavy rain, with which existing means of drainage were unable to cope. Lord de Freyne is erecting huts for the dislodged tenantry, and about twenty men were still engaged at Christmas in clearing the main road from its peaty covering.

ON December 22 the airship Lebaudy II. made its thirtieth experiment in aërial direction at Moisson, near Mantes. In these voyages the Lebaudy II., the volume of which has been brought up to 2063 metres, returned each time to the shed which shelters it, after having gone away to distances so great as ten miles. The length of the balloon is 64 metres, and its regular crew consists of three people. Several times, however, it has taken passengers, as many as six persons having ascended at one time. The speed attained by its own propulsion, measured with a registering anemometer, may be estimated at 40 kilometres per hour. The airship has been taken out in wind blowing at 5 or 6 kilometres, and in rain. It has risen to the altitude of 500 metres. The ascent of December 22 was the last of the autumn campaign, eighteen ascents having been made during the months of November and December. During this season experiments were made to decide whether an astronomer aboard an airship can know the precise geographical position of the balloon when he makes his observation. An ascent was made between $\mathrm{I}$ and 2 a.m. on a foggy morning. In the car had been taken an acetylene searchlight equalling 100,000 lamps of ten candles each, like those at the Exposition of the Grand Palais. The balloon was invisible to persons on the earth, and the earth itself could not be seen by the aerronauts. But the light could easily be distinguished, and its novements 